\title{
Bag Toss Game based on Internet of Education Things (IoET) for the Development of Fine Motor Stimulation in Children 5- 6 Years 0ld
}

\author{
Seiba Shonia1, Novian Anggis Suwastika², Rahmat Yasirandi ${ }^{3}$ \\ 1,3Informatics Study Program, School of Computing, Telkom University, Bandung, \\ Indonesia \\ 2Information Technology Study Program, School of Computing, Telkom University, \\ Bandung, Indonesia \\ E-mail: 1seiba.shonia@gmail.com, 2anggis@telkomuniversity.ac.id, \\ 3batanganhitam@telkomuniversity.ac.id
}

Received May 18, 2020; Revised July 9, 2020; Accepted August 1, 2020

\begin{abstract}
The development of a child's motor skills starts when a child is 0 months old to 6 years old. In general, the development of motor skills divided into fine motor development and gross motor development. Fine motor development is a development that involves small muscles to follow certain movements. An example of a game activity to help stimulate small muscle development is the Bag Toss game. This game helps stimulate fine motor development by increasing eye coordination with the hand. In addition to the types of activities that boost fine motor development, it also requires the ability to monitor, record, and process the results of children's activities to assess and analyze the status of a child's fine motor development. In this study, we developed the Bag Toss game system that connected to the Internet of Things (IoT) platform. Bag Toss game has linked with a sensor that will record children's play activities. The results of recording data will be sent to the IoT platform to be processed and presented through the internet network. The implementation of IoT for educational purposes is known as the Internet of Educational Things (IoET). The system built will be tested in terms of functionality, reading accuracy and child assessment. The functionality of the system works $100 \%$ according to predetermined component functions, as well as for $100 \%$ successful reading accuracy for the scenario of throwing distances of 1 meter and 1.5 meters. In addition, the average delay time for every hole is 0.62 seconds. The delay value can still be tolerated and does not interfere with the game when the child assessment is conducted. The child assessment involved 4 children, the results obtained that 3 children are in the Well Development (BSH) stage and 1 child in Very Well Development (BSB) stage.
\end{abstract}

Keywords: fine motor development, eye and hand coordination, bag toss game, IoT, IoET. 


\section{INTRODUCTION}

The development of a child's motor skills starts when the child is born until the age of 6 years old [1] [2]. In this age range, the child's motor development will increase rapidly and is known as the golden age of growth. In general, children's motor development divided into two groups, namely fine motor development and gross motor development [3]. Fine motor development is an event of physical development which includes activities involving small muscles (hands) and coordination between the hands with the eyes or other senses that ensures accuracy in motion [4] [5]. In the golden age range, children must get a stimulus to ensure that the child's fine motor development achieved [6] [7] [8]. Examples of activities to stimulate fine motor development are throwing and capturing objects [7]. When the child throws the ball, the child makes visualization of how fast and how high the object thrown, then responds by throwing the item correctly.

There are official instruments for evaluating fine motor development in each country, for example in Indonesia using the "Pre-Development Examination Questionnaire (KPSP)" [9], while in the United States using the Denver Development Screening Test (DDST) and Centers for Disease Control and Prevention (CDC) checklist [10] [11] [12]. Children must be trained and given stimulus to complete motor development checklists. According to Grantham-McGregor et al. in his research about the effects of stimulation for the development of stunting children, the most effective stimulus for children is implemented stimulus in games [13]. According to the Montessori theory, the form of stimulus must be related to children's daily activities because it is related to physical abilities and independence of children in solving problems [14] [15]. Games that involve small muscles and eye-hand coordination are Bag Toss games [14]. The rule of the Bag Toss game is to throw a beanbag into the board hole that has provided. Because the Bag Toss game requires independence and concentration, this game is suitable for children with a minimum age of 5 years and above.

In Indonesia, children at the age of 5 and 6 already attend school at the kindergarten level [16]. At school hours, parents can no longer provide a direct stimulus for the child's motor development. The issue in this research is how to make a Bag Toss game that can help teachers in schools to provide a stimulus for fine motor development to children and provide automatic recording and processing of data on game activities. Additional is how the data from the activities can be accessed by parents anytime and anywhere. To resolve this issue, we built a system that can perform data reading at the initial node, processing data in the cloud, and presenting data at the user's node. All communication between nodes and the cloud uses the internet network. In the process of reading, processing, and presenting data carried out automatically between machines to machines (M2M), and because the implementation of this system for educational fields and devices, this system is referred to as the Internet of Educational Things (IoET) [17] [18]. 
The methodology of this research following 5 steps, namely a study of literature, data collection, system design, device testing, and analysis of results. The study of literature is a stage to collect references regarding IoT devices and children's fine motor development. The references that have been obtained then combined in the data collection stage. Furthermore, the IoT device will be designed in the system design stage and after that, the device will be tested in the device testing process. The results of the device testing process will be analyzed in the analysis results stage.

This research conducted to build Bag Toss system based-on IoET and analyze system performance based on functionality tests, system performance, and child assessment. Functionality testing carried out to validate all components of the system working correctly by predetermined functions. System performance testing tests the accuracy of reading, processing, and presenting data for each activity undertaken. Child assessment conducted to see the condition of children's fine motor development after playing Bag Toss. Scenarios to test the system performed with two levels of throwing distance.

This study consists of six parts, an introduction that discusses the background of the study. The next section discusses related studies, which include research on stimuli of fine motor development in children. The originality of this study explained in third chapter. The technologies adopted in this study, the rules of the Bag Toss game and the proposed solutions implemented in this study discussed in the fourth chapter. The fifth chapter discusses the detailed proposed solutions implemented. The results of the system built in the previous chapter were experimented and analyzed based on predetermined testing parameters. The final chapter concludes with the results of studies, methodology, implementation, and analysis of system results.

\section{RELATED WORKS}

\subsection{Fine Motor Skills Development}

According to research conducted by Andri et al., children ages 5-6 years have been able to coordinate the eye, hand, arm, and body movements simultaneously after doing various play activities [19]. The research aims to identify children's fine motor skills development in various play activities in Group B Kindergartens in Parakeet Clusters, Banyu Urip, Purworejo. There are eight play activities carried out, such as cutting, sticking, coloring, weaving, stringing, shaping, shading, and copying words or numbers. Subjects were 97 children ages 5-6 years, and one of the aspects assessed in this study was the development of eye-hand coordination. The results indicate that 5 children are in the Early Development stage (MB), 39 children are in the Well Development stage (BSH), and 53 children are in the Very Well Development stage (BSB).

In another study, the Finger Painting technique was used as a treatment to train eye-hand coordination [20]. Finger painting is a technique of painting 
using fingers, it can train eye and hand movements. The subjects in this study were 18 children ages 5-6 years in Sartika I Kindergarten, Sumurgenuk, Babat Lamongan District. The results indicated an increase of $26.2 \%$ in eyehand coordination development after treatment performed, from 29 children (69\%) to 40 children (95.2\%).

Sherrill explained that there are various game activities to support fine motor development. In her book, Sherril mentions Bag Toss game (throwing game) [7]. This game can help strengthen wrist development and improve eye-hand coordination of a child. Not only a throwing game, but Sherril mentions that catching games can also improve the eye-hand coordination of a child. The catching game activity is also listed in KPSP, as can be seen in 72 months and 66 months child development checklist which stated "Can a child catch a small ball as big as a tennis ball/baseball using only his hands?" [25].

Table 1. Comparison of Fine Motor Treatment Results

\begin{tabular}{|c|l|l|l|}
\hline No & \multicolumn{1}{|c|}{$\begin{array}{c}\text { Research } \\
\text { Topic }\end{array}$} & \multicolumn{1}{|c|}{$\begin{array}{c}\text { Title of Paper / } \\
\text { Book }\end{array}$} & \multicolumn{1}{c|}{ Results } \\
\hline 1 & $\begin{array}{l}\text { Development } \\
\text { of Eye-Hand } \\
\text { Coordination } \\
\text { through Play } \\
\text { Activities }\end{array}$ & $\begin{array}{l}\text { Identification of Fine } \\
\text { Motor Skill in Play } \\
\text { Activity }\end{array}$ & $\begin{array}{l}\text { A total 5 children are in the } \\
\text { Early Development stage (MB), } \\
\text { 39 children are in the Well } \\
\text { Development stage (BSH), and } \\
53 \text { children are in the Very } \\
\text { Well Development stage (BSB). }\end{array}$ \\
\hline \multirow{2}{*}{2} & $\begin{array}{l}\text { Development } \\
\text { of Eye-Hand } \\
\text { Coordination } \\
\text { through Finger } \\
\text { Painting }\end{array}$ & $\begin{array}{l}\text { The Effect of Finger } \\
\text { Painting to the } \\
\text { Development of Fine } \\
\text { Motor on Preschool } \\
\text { Children in Sartika I } \\
\text { Sumurgenuk } \\
\text { Kindergarten Babat } \\
\text { Lamongan }\end{array}$ & $\begin{array}{l}\text { An increase of 26.2\% in eye- } \\
\text { hand coordination } \\
\text { development after treatment } \\
\text { being performed, from 29 } \\
\text { children (69\%) to 40 children } \\
\text { (95.2\%) }\end{array}$ \\
\hline \multirow{3}{*}{3} & $\begin{array}{l}\text { Game Activity } \\
\text { for Eye-Hand } \\
\text { Coordination } \\
\text { Development }\end{array}$ & $\begin{array}{l}\text { Fine Motor Fun, } \\
\text { Grades PK - 1 }\end{array}$ & $\begin{array}{l}\text { Bag Toss game can help } \\
\text { strengthen wrist development } \\
\text { and improve eye-hand } \\
\text { coordination of a child. }\end{array}$ \\
\hline
\end{tabular}

Based on Table 1, it can be inferred that developing fine motor skills, specifically in the aspect of eye-hand coordination through play activities, has a significant impact. However, all the research that has performed still utilizing conventional methods in recording data. It could cause problems in the process of data communication and the accuracy of data activity that is usually caused by human error. In this study, the IoET device will utilized to replace it. The device will assist in improving all the processes of data recording. 


\subsection{Internet of Things (IoT)}

IoT is an embedded technology system into physical objects that use sensors, actuators, and communication to be controlled through internet networks. It involves three steps, namely capturing data using sensors, collecting data over the network, and make a decision based on data analysis [17].

IoT can be implemented in various fields, including in the field of education. Applying IoT in the education field can be referred to as an Internet of Education Things (IoET) [18]. IoET provides more educational value compared to the conventional education system. The following are the benefits of IoET [21].

1. Learning Experience

The system can assist in advising learning, such as giving feedback to the user. This feature could enhance a child's learning experience and help teachers to teach better.

\section{Effective}

The analysis of data recorded by the IoET device produces valuable information. It can help teachers to infer a child's conditions that will be needed to improve a child's understanding in the future. This information certainly can increase the effectiveness of learning.

\subsection{Bag Toss}

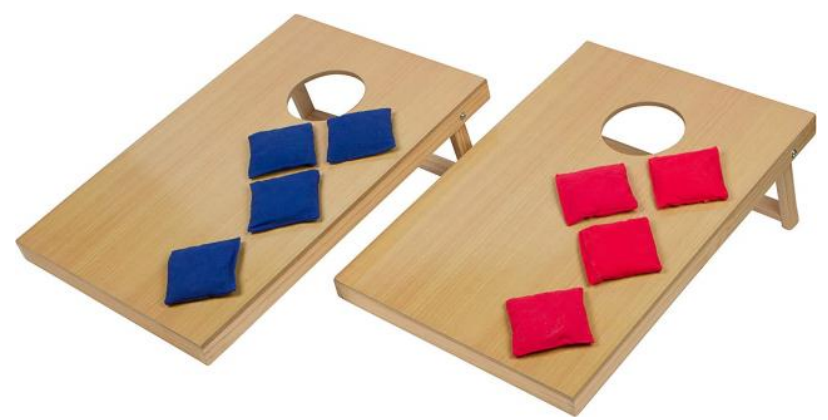

Figure 1. Bag Toss

As can be seen in Figure 1, Bag Toss is a game originated in Germany in the 14th century, and then was rediscovered in the hills of Kentucky over 100 years ago [22]. The game is played by throwing beanbags to a hole in the Bag Toss board. A beanbag is a bag contains corn kernels. In the United States, the game is highly developed. Moreover, they also have associations that organize the Bag Toss tournament, such as the American Cornhole League (ACL), the American Cornhole Association (ACA), and the American Cornhole Organization (ACO) [22] [23]. 


\section{ORIGINALITY}

One of the Spanish government research developed an innovative solution to detect changes in children's psychomotor development through smart toys based on the IoT system [24]. The subjects were 65 children ages 23-37 months, they need to build a tower with five stackable cubes. The sensors in the cubes sent data to a collector module through WiFi. All the tests were video recorded. Furthermore, the results of the test will be scored and analyzed by child development experts. Another research studied the effect of 12 weeks of game education on the motor development of 60 children ages 4-6 years [3]. Children need to play throwing, catching, long jump, vertical jump, running and stopping. The research used a motor performance test protocol developed by Morris in 1980 to asses child motor development.

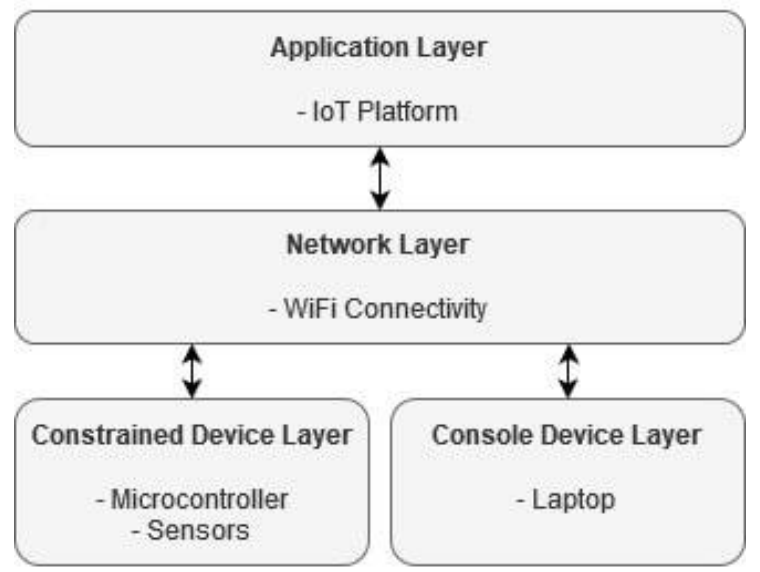

Figure 2. IoT Architecture of Bag Toss Game System

The IoT architecture of the game can be seen in Figure 2 [26]. Constrained Device Layer responsible to collect and gather information from the sensors. Network Layer responsible for transmitting and processing sensor data to the IoT platform. Application Layer is responsible for processing information to the user. The information that has been processed in the Application Layer will be delivered to the Console Device Layer to be displayed to the user. This game helps stimulate fine motor development by increasing eye coordination with the hand. Besides, the system can also monitor, record, and process the results of children's activities to become the status of a child's fine motor development. The system built is tested in terms of functionality, performance and child assessment. Functionality testing performed to validate all components of the system working correctly following predetermined functions. The performance testing performed to test the accuracy of reading, processing, and presenting data for each activity undertaken. Meanwhile, the child assessment conducted to see the condition of children's fine motor development after playing Bag Toss.

Indeed, previous research has utilized IoT to stimulate child motor development, but the analysis still relies on human assistance [24]. Moreover, the study conducted by Hayrettin still uses an entirely 
conventional method [3]. Furthermore, the research that we conduct has the opportunity to be developed with a variety of play activities integrated with the IoT system. It can provide valid assessments, and there will be no human error. All data that will be presented is accurate and effective. The device can also be implemented in a kindergarten. It can help the teacher and parents to monitor and stimulate children's fine motor skill.

\section{SYSTEM DESIGN}

\subsection{System Architecture}

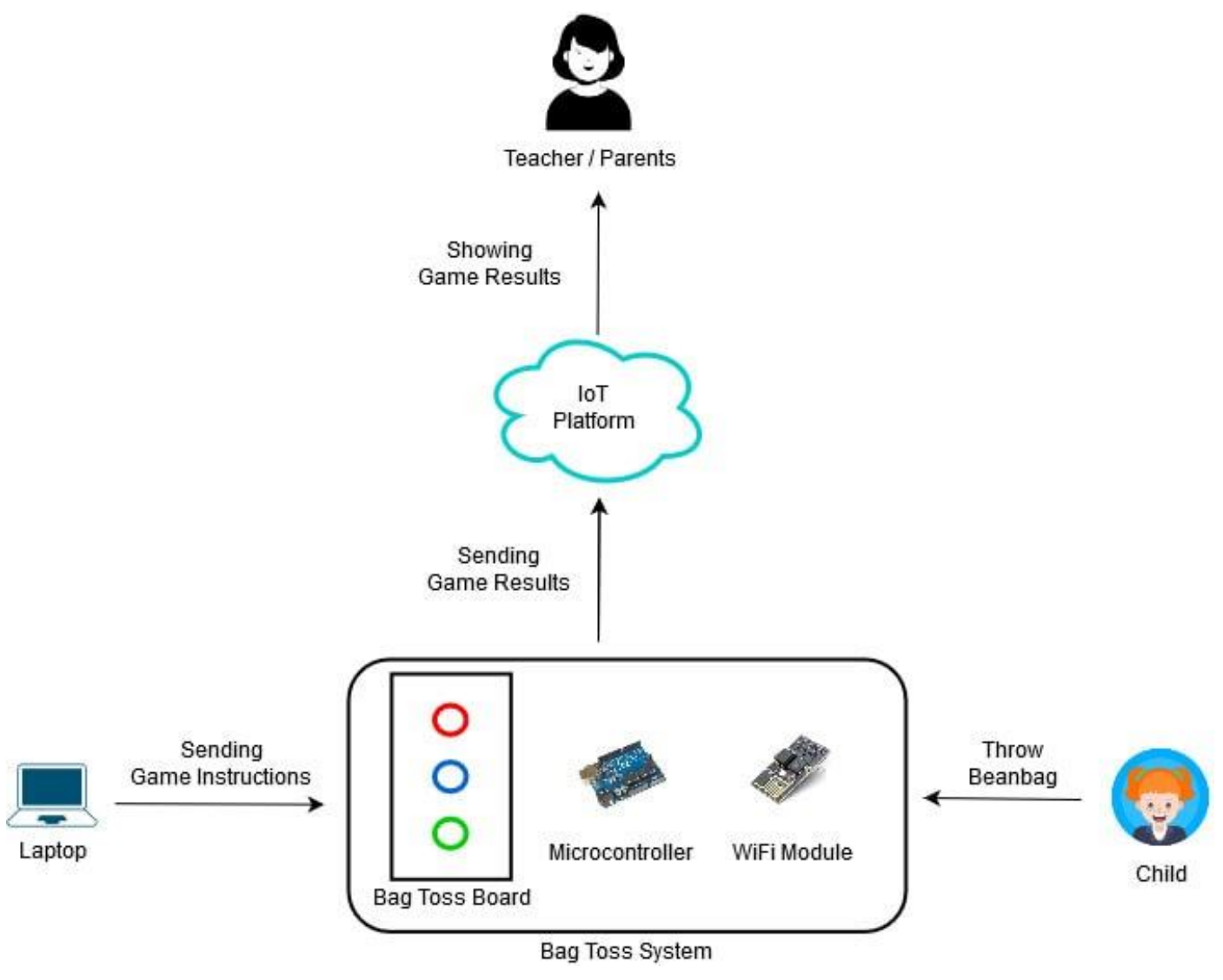

Figure 3. System Architecture of Bag Toss Game

In Figure 3 to start the game, a game instruction will be sent from the laptop to the microcontroller through USB cable, then the child will take a beanbag then throw it to the Bag Toss board. Microcontroller functions to calculate the score of the game, while the WiFi module functions to send the results of the game score from the microcontroller to IoT platform. The IoT platform will process the results of the game score and displayed it for teacher or parents.

A separate WiFi module is required because we use Arduino Uno as a microcontroller. This microcontroller does not have an embedded WiFi. In addition, this system is using a hard code program. Thus, connecting a USB 
cable from a microcontroller to the laptop is required for changing the code when adjustment needed.

\subsection{System Flowchart}

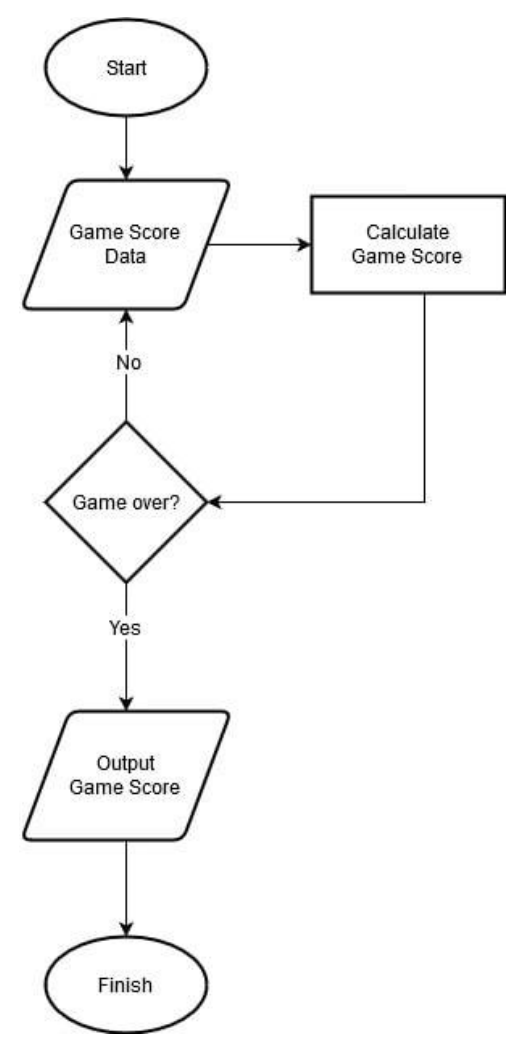

Figure 4. System Flowchart of Bag Toss Game

In Figure 4 the game score data will be entered and calculated by the system until the game is finished. After the game is finished, the system output will be the final game score.

\subsection{System Device Components}

The followings are the system components implemented in the Bag Toss.

1. Microcontroller

Used to manage and run system devices.

2. LED Strip Lights

Used to give color marks to the Bag Toss board holes.

3. WiFi Module

Used to send game score data from the microcontroller to the IoT platform.

4. Infrared Sensor

Used to count the number of beanbags that enter the Bag Toss board hole. 
Figure 5 shown a system component design that has been installed. Infrared sensor IR-1 is a sensor for the green holes, IR-2 is for blue the holes and IR-3 is for the red holes. All sensors are powered by $5 \mathrm{~V}$, while the WiFi module is powered by 3.3V. LED strip lights are installed separately from the microcontroller and powered by $12 \mathrm{~V}$. The system component design that has been implemented can be seen in Figure 6.

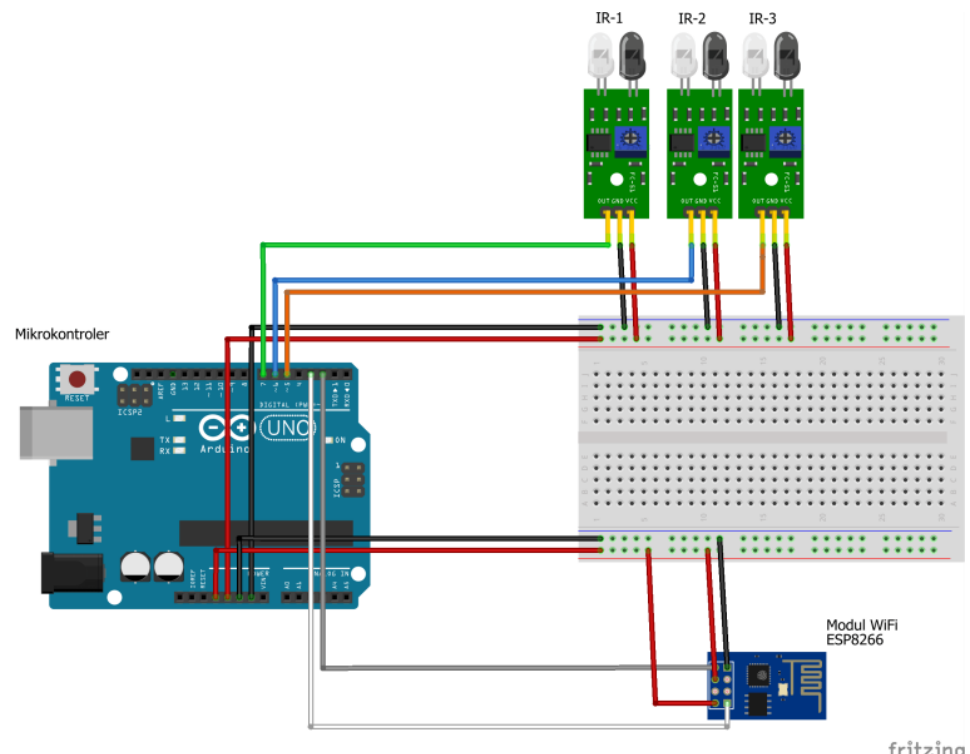

Figure 5. System Component Design
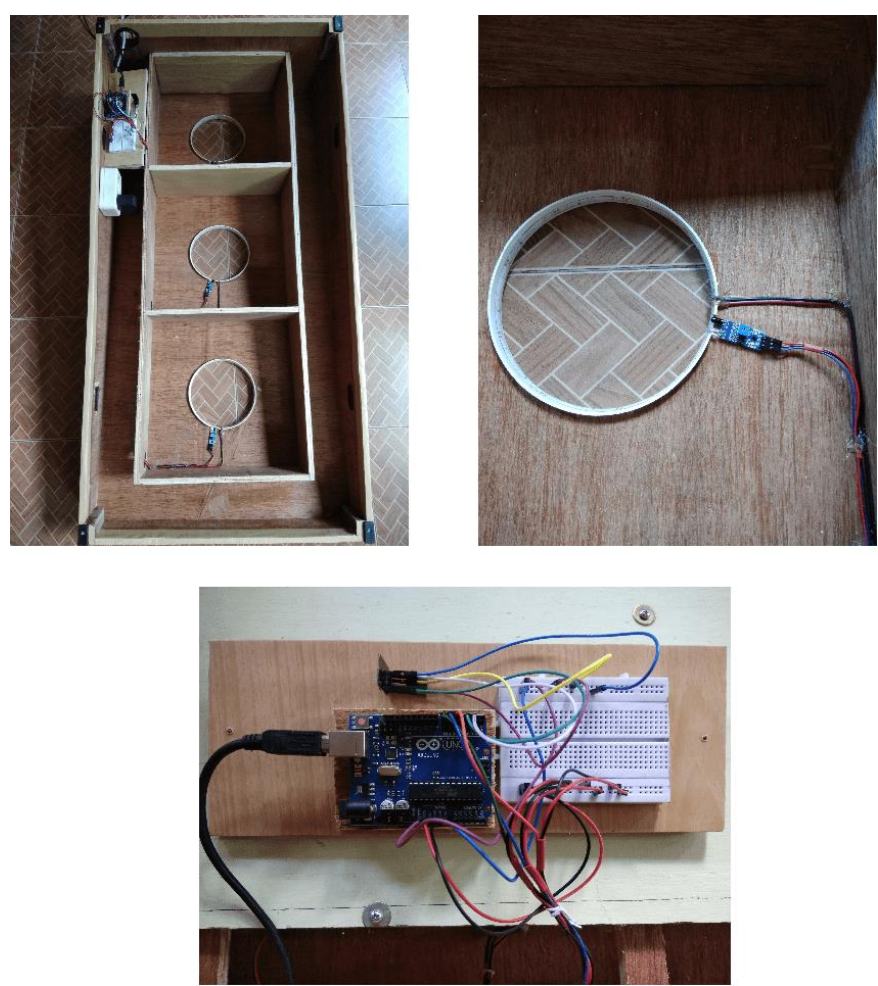

Figure 6. Implemented System Component 


\subsection{Design of Bag Toss Board and Beanbag}
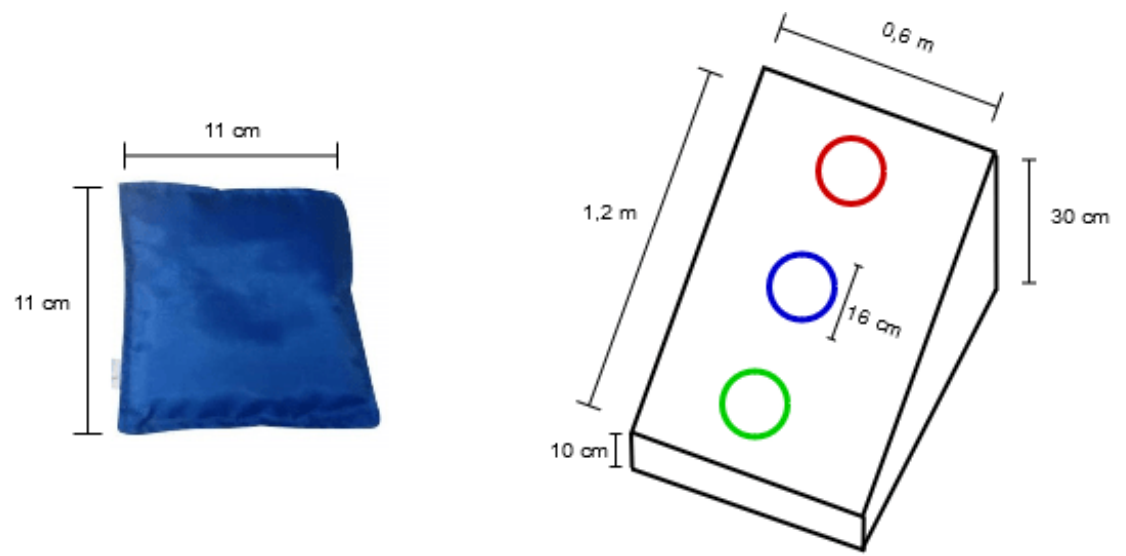

Figure 7. Design of Bag Toss Board and Beanbag

The followings are the design of the Bag Toss board and Beanbag with sizes adjusted to the standard rules set by the ACA [22]. The design of the Bag Toss board is slightly modified from the original design. It can be seen in Figure 7, the game board hole design is made into 3 holes, whereas in the original design there is only 1 hole. The purpose is to give an impression of a more interesting and varied game for children. The results of the design can be seen in Figure 8.

1. Board size is $1.2 \mathrm{~m} \times 0.6 \mathrm{~m}$.

2. Each hole diameter is $16 \mathrm{~cm}$.

3. The height of the front of the board is $10 \mathrm{~cm}$.

4. The height of the back of the board is $30 \mathrm{~cm}$.

5. Beanbag size is $11 \mathrm{~cm} \times 11 \mathrm{~cm}$.

6. Beanbag weight is $150 \mathrm{gr}$.
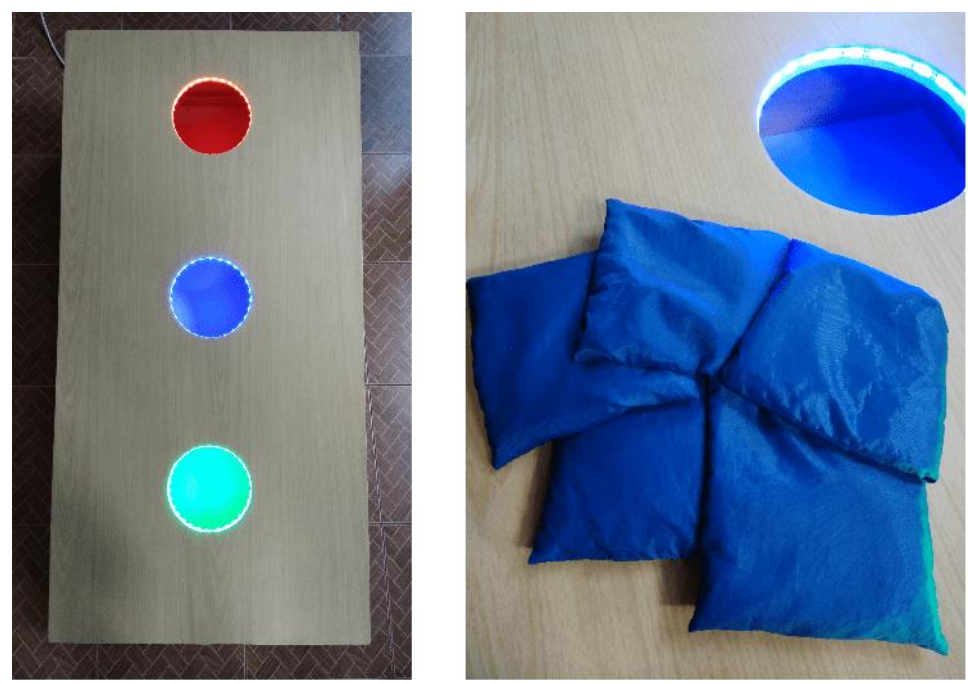

Figure 8. Results of Bag Toss Board and Beanbag Design 


\subsection{Bag Toss Game Rules}

The game rules refer to the rules set by the ACA, but slightly adjusted to the ability of children ages 5-6 years [22]. The followings are the rules of the game.

1. This game needs a guidance.

2. The maximum distance of a player to throw a beanbag is $1.5 \mathrm{~m}$.

3. The number of levels that must be played is 2 levels.

4. Each level requires players to throw 5 beanbags.

5. The game time for each level is 3 minutes.

6. At level 1, players will throw beanbags from a distance of $1 \mathrm{~m}$.

7. At level 2, players will throw beanbags from a distance of $1.5 \mathrm{~m}$.

8. The holes in the board will be given a different color, namely green, blue, and red.

9. Players can freely throw beanbags in any hole on the board.

10. Each beanbag that enters the green hole will be counted as 1 point.

11. Each beanbag that enters the blue hole will be counted as 3 points.

12. Each beanbag that enters the red hole will be counted as 5 points.

13. Any beanbags that do not enter the hole will not be counted.

The final game scores at each level will be used to determine the condition of a child's motor development that refers to the motor conditions listed in KPSP [25]. The conversion of the game scores can be seen in Table 2 .

Table 2. Game Score Conversion to Motor Development Conditions

\begin{tabular}{|c|c|}
\hline Condition of Motor Development & Total Score \\
\hline Zero Development (BB) & 0 \\
\hline Early Development (MB) & $1-5$ \\
\hline Well Development (BSH) & $6-15$ \\
\hline Very Well Development (BSB) & $16-25$ \\
\hline
\end{tabular}

$\mathrm{BB}$ is a condition where the child is completely unable to throw the beanbag right into the hole, while $\mathrm{MB}$ is a condition where the child begins to throw right into the hole and get a minimum score of 1 point. Likewise, BSH is a condition where the child has developed quite well and got a minimum score of 6 points and BSB is a condition where the child has developed very well and got a minimum score of 16 points.

The score conversion in Table 2 is determined based on the level of difficulty of the game. The green hole is the lowest level, the blue hole is moderate level and the red hole is the highest level. The maximum score range for the MB condition is obtained from the assumption that the child can only throw a beanbag 5 times in a row only on the green hole. Likewise, the BSH condition obtained from the assumption that the child can only throw a beanbag 5 times in a row only on the blue hole, and the BSB condition is where the child can only throw a beanbag 5 times in a row only on the red hole. 
There will be guidance either from a teacher or parents before the children play the game. To keep the children continues to play rewarding a gift may be needed, therefore the children have a motivation to finish the game. But if the children did not throw any beanbag in 3 minutes since the game start, they will be disqualified and the scores will not be counted.

\subsection{System Testing}

The followings are the test scenarios performed.

1. System Functionality

System functionality test carried out to validate all components of the system working correctly in accordance with predetermined functions.

- LED Strip Lights Functionality Testing whether the LED lights are on when turned on.

- Infrared Sensor Functionality Testing whether the infrared sensor can function as a counter.

- Microcontroller Functionality Testing whether the microcontroller can function to calculate game scores.

- WiFi Module Functionality Testing whether the WiFi module can send game scores to the IoT platform.

2. System Performance

Testing the accuracy of reading, processing, and presenting data for each activity undertaken. There are two parameters tested in system performance.

- Data Communication

Measuring the delay and testing whether the data can be sent correctly through the system and displayed in a web application.

- Accuracy of Data Activity

Testing the accuracy of all sensors reading and processing.

3. Child Assesment

This test is conducted to see the condition of children's fine motor development after playing Bag Toss. The test will be carried out on 4 children, each child will be playing twice at each level. The results of the test will be a comparison of fine motor conditions between Test 1 and Test 2 based on Table 2. In addition, the average score of each child will also be counted. 


\section{EXPERIMENT AND ANALYSIS}

\subsection{Test Results}

The testing was carried out from the throwing distance of 1 meter and 1.5 meters. Then, the results of the test will be displayed on Thingspeak, which is one of the IoT analytic platform services. The followings are the results of the tests.

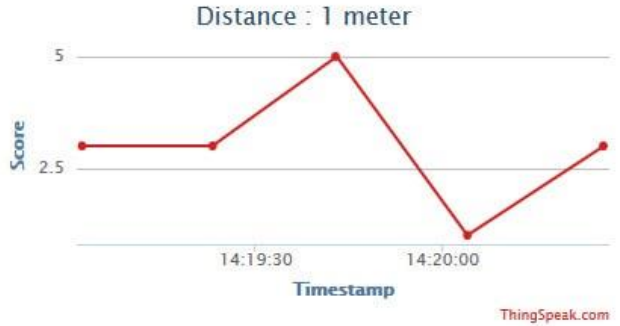

(a)

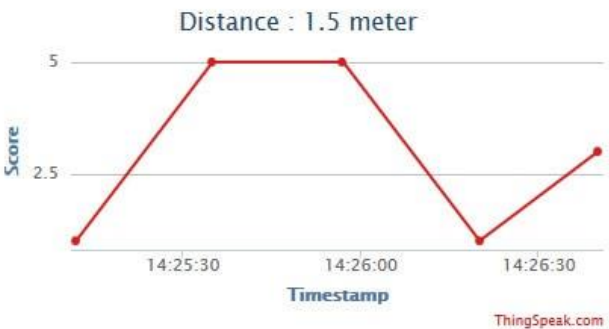

(b)

Figure 9. Test Results (a) Distance of 1 meter; (b) Distance of 1.5 meters

Figure 9 (a) shown the result obtained from the throwing distance of 1 meter. While Figure 9 (b) shown the result obtained from the throwing distance of 1.5 meters. The results analysis will be explained in the next part.

\subsection{Analysis of Test Results}

The system process can be seen in Figure 10. The system starts after the device connected to the WiFi, then the system reads the pin input from the sensor, and after that, the timer will start. As long as the timer has not stopped, the system will continue to loop to check the sensor detection in each hole. When the sensor detected a beanbag, the system will count it as a game score that will be sent and displayed on the IoT platform.

The game time (timer) for each level lasts for 3 minutes, it is based on the time needed to make sure that the game score data is completely displayed on the IoT platform. The calculation as follows in Equation 1.

$$
\begin{aligned}
& \begin{array}{ll}
\text { Game time } & =180 \text { seconds }=3 \text { minutes } \\
\text { Waiting for data to be displayed } & =15 \text { seconds } \\
\text { Beanbag to throw in each level } & =5 \text { beanbags }
\end{array} \\
& \begin{aligned}
\text { Remaining time } & \text { (game time })-(\text { time for data to be displayed } \mathrm{X} \\
& \text { beanbag to throw in each level) } \\
= & (180)-(15 \times 5) \\
= & 105 \text { seconds }=1.75 \text { minutes }
\end{aligned}
\end{aligned}
$$

Meanwhile, the remaining game time could be enough to use for the children to prepare and aim before throwing beanbags. 


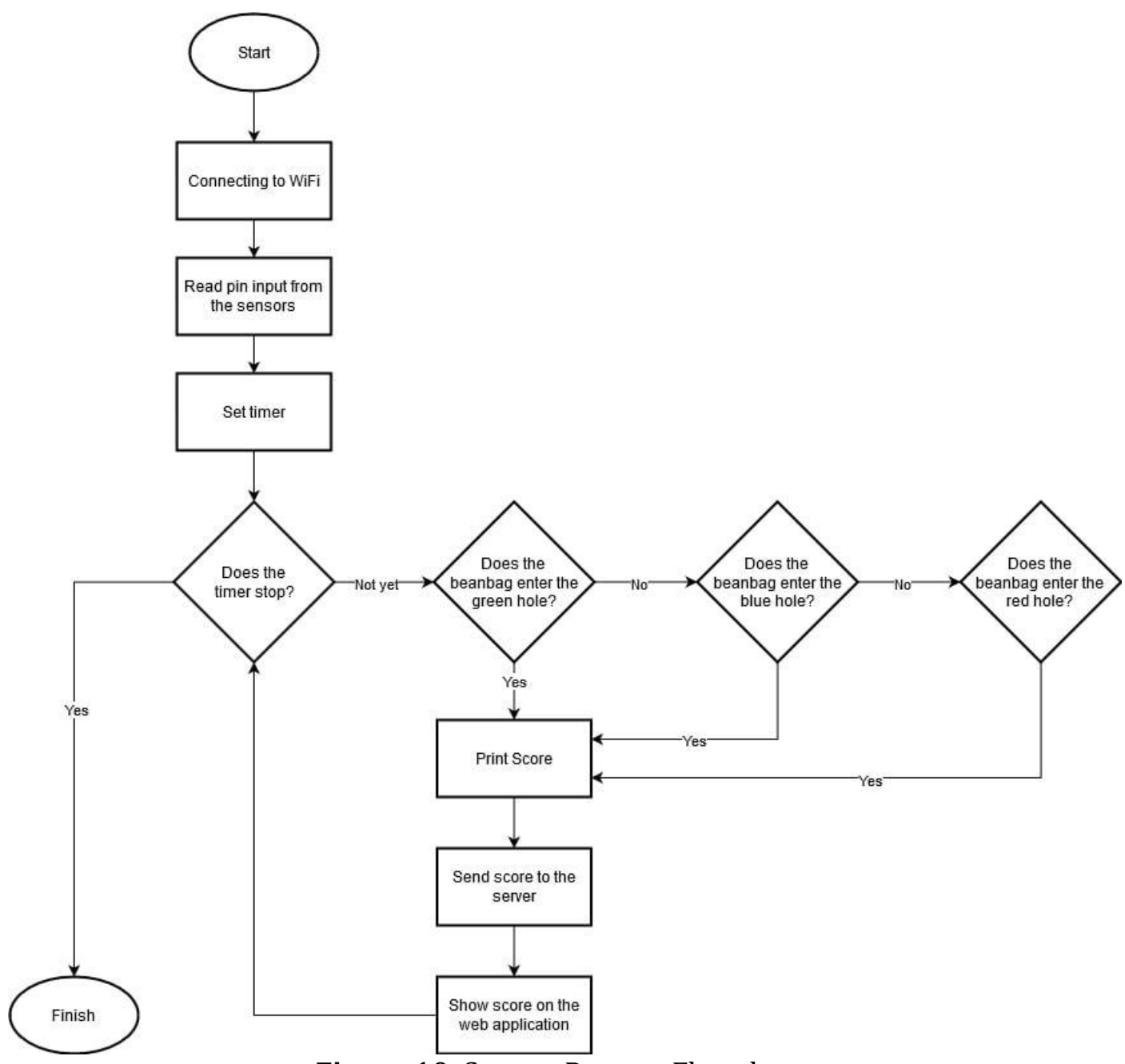

Figure 10. System Process Flowchart

\subsubsection{System Functionality}

There are 4 system components tested in the system functionality, namely the microcontroller, infrared sensor, WiFi module, and LED strip lights. From the results of the tests, it can be inferred that all components of the system can function properly as to be seen in Figure 9. The details of each component functionality can be seen in Table 3.

Table 3. System Component Functionality

\begin{tabular}{|c|l|l|c|}
\hline No & System Component & \multicolumn{1}{|c|}{ Function } & Working \\
\hline 1 & Microcontroller & $\begin{array}{l}\text { Run a program to calculate game } \\
\text { scores }\end{array}$ & Yes \\
\hline 2 & Infrared Sensor & $\begin{array}{l}\text { Detecting each beanbag that } \\
\text { enters the hole }\end{array}$ & Yes \\
\hline 3 & WiFi Module & $\begin{array}{l}\text { Sending game score results to } \\
\text { the IoT platform through WiFi }\end{array}$ & Yes \\
\hline 4 & LED Strip Lights & Put a color mark on each hole & Yes \\
\hline \multicolumn{2}{r|r}{ Test Results } & $100 \%$ \\
\hline
\end{tabular}




\subsubsection{System Performance}

There are 2 parameters analyzed in system performance, namely data communication and the accuracy of data activity.

1. Data Communication

The communication of data is performed through WiFi between the microcontroller and the IoT platform. The followings are the details of all data communication from each hole.

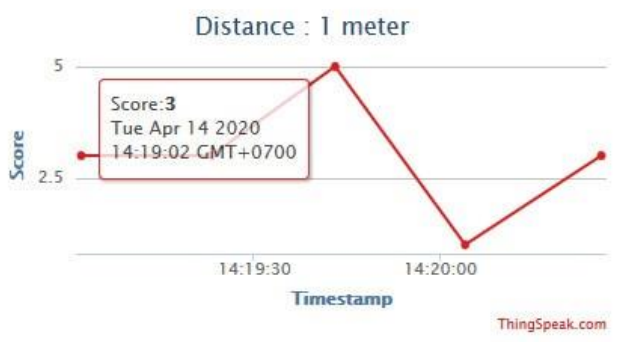

(a)

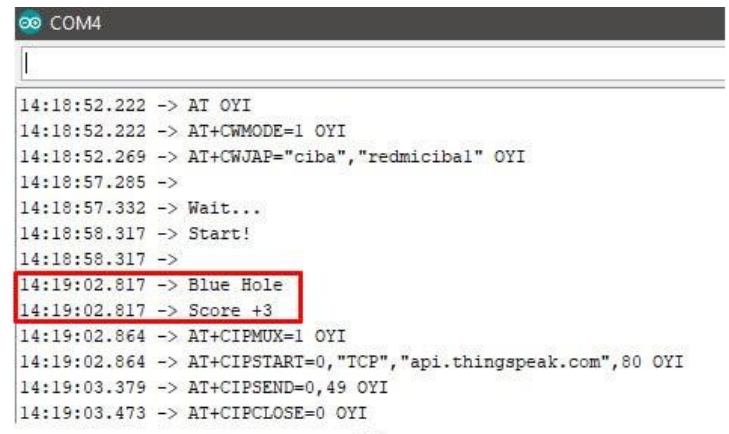

Figure 11. Details of game results in the blue hole (a) IoT platform (b) Serial monitor in the microcontroller

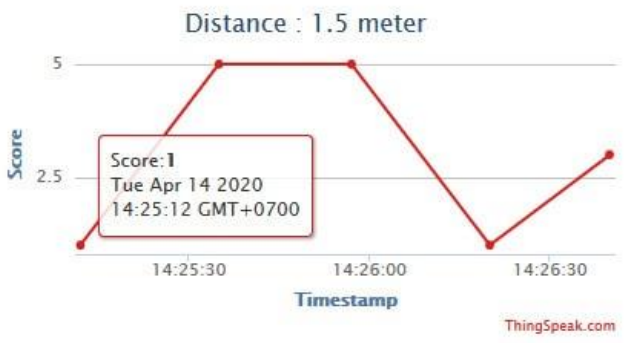

(a)

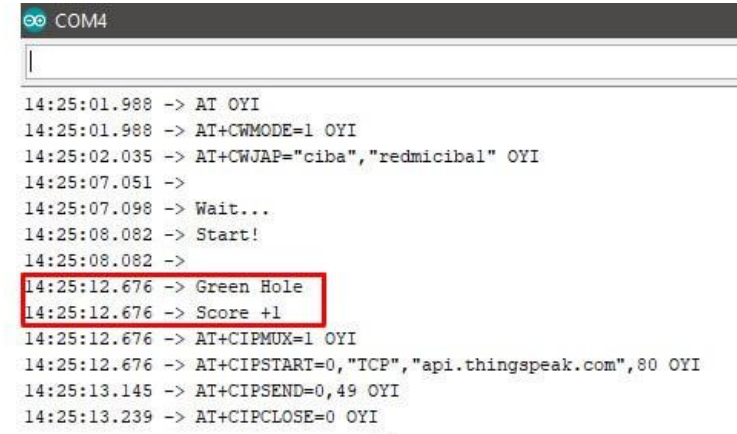

Figure 12. Details of game results in the green hole (a) IoT platform (b) Serial monitor in the microcontroller

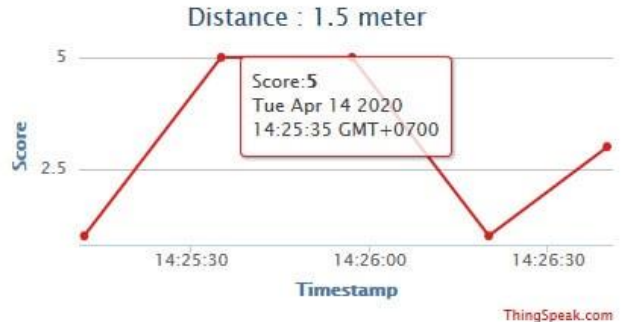

(a)

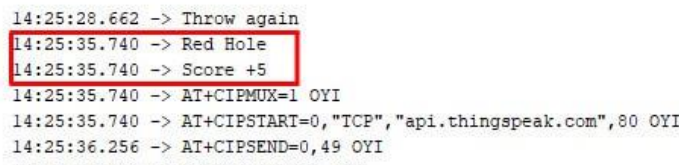

(b)

Figure 13. Details of game results in the red hole (a) IoT platform (b) Serial monitor in the microcontroller

As can be seen in Figure 11, Figure 12, and Figure 13, the time information recorded from each hole on the serial monitor of the 
microcontroller is accurately the same as the time shown on the IoT platform. Thus, it can be said that the performance of data communication runs $100 \%$.

Table 4 . Green Hole Delay

\begin{tabular}{|c|c|c|c|}
\hline \multirow{2}{*}{ No } & \multicolumn{2}{|c|}{ Time } & \multirow{2}{*}{ Delay (s) } \\
\cline { 2 - 3 } & Data read & Data push & \\
\hline 1 & $16: 44: 48.904$ & $16: 44: 49.654$ & 0.75 \\
\hline 2 & $16: 45: 06.389$ & $16: 45: 06.858$ & 0.47 \\
\hline 3 & $16: 45: 23.687$ & $16: 45: 24.296$ & 0.61 \\
\hline 4 & $16: 45: 41.204$ & $16: 45: 41.673$ & 0.47 \\
\hline 5 & $16: 45: 58.502$ & $16: 45: 59.111$ & 0.61 \\
\hline \multicolumn{3}{|c}{ Average Delay } & 0.58 \\
\hline
\end{tabular}

Table 5. Blue Hole Delay

\begin{tabular}{|c|c|c|c|}
\hline \multirow{2}{*}{ No } & \multicolumn{2}{|c|}{ Time } & \multirow{2}{*}{ Delay (s) } \\
\cline { 2 - 3 } & Data read & Data push & \\
\hline 1 & $17: 04: 48.837$ & $17: 04: 49.587$ & 0.75 \\
\hline 2 & $17: 05: 06.229$ & $17: 05: 06.792$ & 0.56 \\
\hline 3 & $17: 05: 23.902$ & $17: 05: 24.418$ & 0.52 \\
\hline 4 & $17: 05: 41.856$ & $17: 05: 42.419$ & 0.56 \\
\hline 5 & $17: 05: 59.655$ & $17: 06: 00.264$ & 0.61 \\
\hline \multicolumn{3}{|c}{ Average Delay } & 0.60 \\
\hline
\end{tabular}

Table 6. Red Hole Delay

\begin{tabular}{|c|c|c|c|}
\hline \multirow{2}{*}{ No } & \multicolumn{2}{|c|}{ Time } & \multirow{2}{*}{ Delay (s) } \\
\cline { 2 - 3 } & Data read & Data push & \\
\hline 1 & $17: 11: 25.979$ & $17: 11: 26.682$ & 0.70 \\
\hline 2 & $17: 11: 44.871$ & $17: 11: 45.527$ & 0.66 \\
\hline 3 & $17: 12: 02.638$ & $17: 12: 03.294$ & 0.66 \\
\hline 4 & $17: 12: 20.123$ & $17: 12: 20.779$ & 0.66 \\
\hline 5 & $17: 12: 37.937$ & $17: 12: 38.593$ & 0.66 \\
\hline \multicolumn{3}{|c}{ Average Delay } & 0.67 \\
\hline
\end{tabular}

Delay testing carried out 15 times with 5 times for each hole. The delay time is obtained based on the time when the data is read by the sensor and the time when the data is push to the IoT platform. As can be seen in Table 4, Table 5, and Table 6, the average delay of the green hole is 0.58 seconds, the blue hole is 0.60 seconds and the red hole is 0.67 . In addition, the average delay time for every hole is 0.62 seconds. The delay value can still be tolerated and does not interfere with the game when the child assessment is conducted.

Sending data to the IoT platform highly depend on the internet speed. As a consequence, the speed when sending the data may vary. The details of the internet speed when the testing is carried out can be seen in Figure 14. 


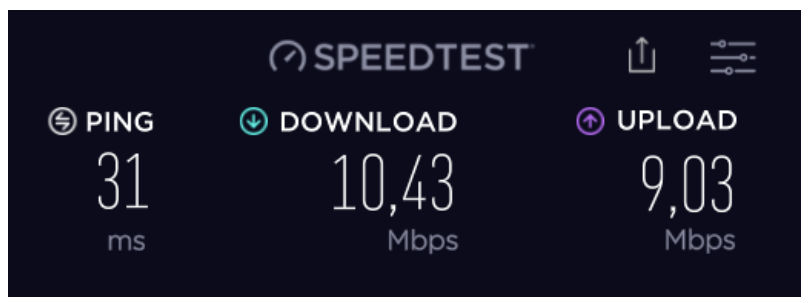

Figure 14. Internet Speed

2. Accuracy of Data Activity

Based on the test results, the system can detect every beanbag that enters the target hole accurately $100 \%$. The system has also been able to determine the score obtained at each target hole. Figure 11, shows that the blue hole is 3 points, also Figure 12 which records scores for green holes by 1 point and Figure 13 which records scores for red holes by 5 points. Scores recorded on the serial monitor are the same as scores recorded on the IoT platform.

\subsubsection{Child Assessment}

The assessment involved 4 children, as can be seen in Figure 15.

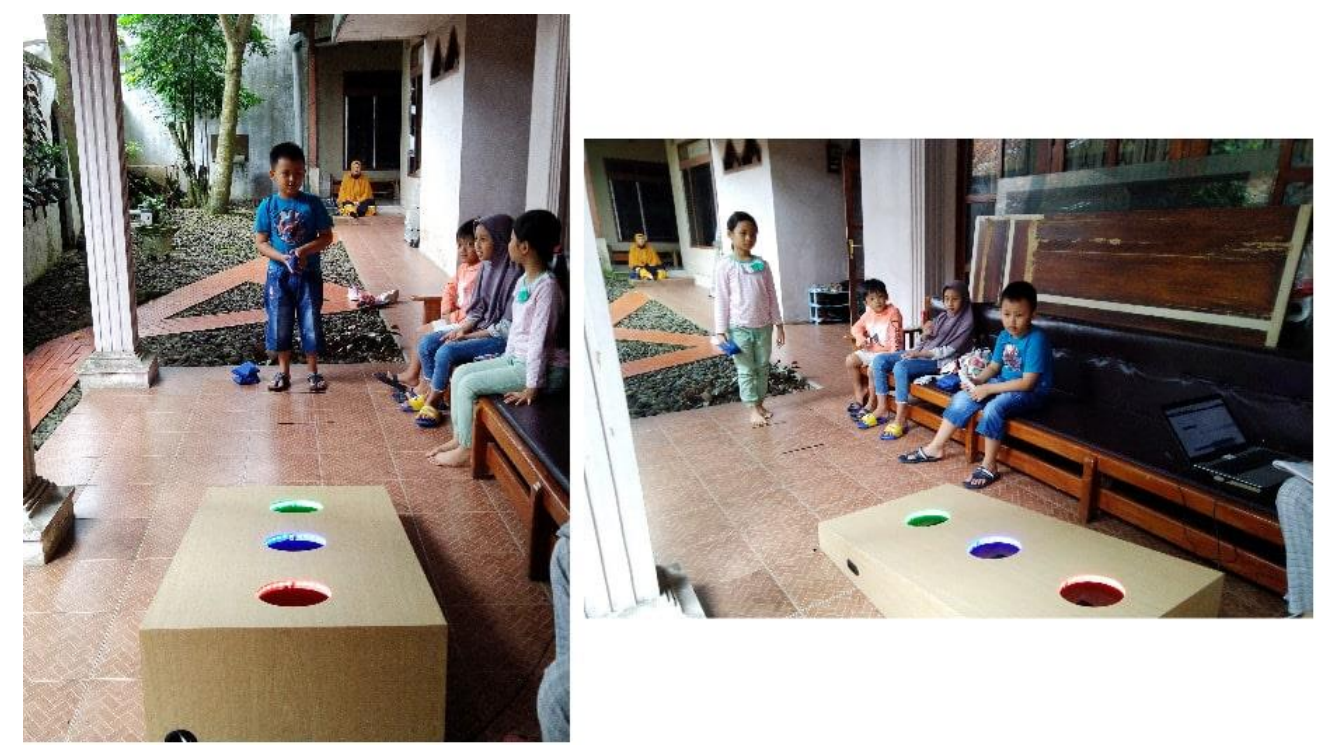

Figure 15. Child Assessment

Table 7 is the game score result from throwing distance of 1 meter, while Table 8 is from a distance of 1.5 meters. The average score obtained at a distance of 1 meter ranges from $7-21$ points and for a distance of 1.5 meters ranges from 5 - 18.5 points.

As can be seen in Table 9, the first child shows a very good development, the condition of this child's motor development increases in every test. The second child experienced a decrease in motor development conditions from BSH to MB while playing from a distance of 1.5 meters. The motor development condition of the third child was also quite well, although 
there was a decrease in the first test for the throwing distance of 1.5 meters, however during the second test the conditions have increased. As for the fourth child, this child has a very good motor development condition, it can be seen that the condition in all tests are BSB. In conclusion, a total of 3 children are in the BSH condition, while the other one is in the BSB condition.

Table 7. Assesment Results from a Distance of 1 meter

\begin{tabular}{|c|c|c|c|c|c|c|c|c|c|c|c|c|c|c|}
\hline \multirow{3}{*}{ Child - } & \multirow{3}{*}{ Age } & \multicolumn{6}{|c|}{ Test 1} & \multicolumn{6}{|c|}{ Test 2} & \multirow{3}{*}{$\begin{array}{c}\text { Avg } \\
\text { Score }\end{array}$} \\
\hline & & \multicolumn{5}{|c|}{ Throw - } & \multirow{2}{*}{$\begin{array}{l}\text { Total } \\
\text { Score }\end{array}$} & \multicolumn{5}{|c|}{ Throw - } & \multirow{2}{*}{$\begin{array}{l}\text { Total } \\
\text { Score }\end{array}$} & \\
\hline & & 1 & 2 & 3 & 4 & 5 & & 1 & 2 & 3 & 4 & 5 & & \\
\hline 1 & 0 & 0 & 0 & 0 & 3 & 0 & 3 & 5 & 3 & 0 & 3 & 0 & 11 & 7 \\
\hline 2 & 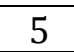 & 3 & 1 & 3 & 3 & 0 & 10 & 3 & 3 & 0 & 1 & 0 & 7 & 8.5 \\
\hline 3 & 6 & 1 & 3 & 3 & 0 & 1 & 8 & 1 & 3 & 3 & 3 & 0 & 10 & 9 \\
\hline 4 & 6 & 5 & 3 & 5 & 3 & 5 & 21 & 3 & 5 & 5 & 3 & 5 & 21 & 21 \\
\hline
\end{tabular}

Table 8. Assesment Results from a Distance of 1.5 meters

\begin{tabular}{|c|c|c|c|c|c|c|c|c|c|c|c|c|c|c|}
\hline \multirow{3}{*}{ Child - } & \multirow{3}{*}{ Age } & \multicolumn{6}{|c|}{ Test 1} & \multicolumn{6}{|c|}{ Test 2} & \multirow{3}{*}{$\begin{array}{c}\text { Avg } \\
\text { Score }\end{array}$} \\
\hline & & \multicolumn{5}{|c|}{ Throw - } & \multirow{2}{*}{$\begin{array}{l}\text { Total } \\
\text { Score }\end{array}$} & \multicolumn{5}{|c|}{ Throw - } & \multirow{2}{*}{$\begin{array}{l}\text { Total } \\
\text { Score }\end{array}$} & \\
\hline & & 1 & 2 & 3 & 4 & 5 & & 1 & 2 & 3 & 4 & 5 & & \\
\hline 1 & 6 & 3 & 0 & 1 & 3 & 3 & 10 & 5 & 3 & 3 & 5 & 5 & 21 & 15.5 \\
\hline 2 & 5 & 1 & 3 & 1 & 0 & 0 & 5 & 0 & 3 & 1 & 0 & 1 & 5 & 5 \\
\hline 3 & 6 & 0 & 1 & 3 & 0 & 1 & 5 & 1 & 1 & 0 & 3 & 5 & 10 & 7.5 \\
\hline 4 & 6 & 3 & 3 & 5 & 5 & 0 & 16 & 3 & 5 & 3 & 5 & 5 & 21 & 18.5 \\
\hline
\end{tabular}

Table 9. Assesment Final Condition

\begin{tabular}{|c|c|c|c|c|c|}
\hline \multirow{3}{*}{ Child - } & \multicolumn{4}{|c|}{ Condition } & \multirow{3}{*}{$\begin{array}{c}\text { Final } \\
\text { Condition }\end{array}$} \\
\hline & \multicolumn{2}{|c|}{1 meter } & \multicolumn{2}{|c|}{1.5 meters } & \\
\hline & Test 1 & Test 2 & Test 1 & Test 2 & \\
\hline 1 & MB & $\mathrm{BSH}$ & $\mathrm{BSH}$ & BSB & $\mathrm{BSH}$ \\
\hline 2 & BSH & BSH & MB & MB & BSH \\
\hline 3 & $\mathrm{BSH}$ & $\mathrm{BSH}$ & MB & $\mathrm{BSH}$ & $\mathrm{BSH}$ \\
\hline 4 & BSB & BSB & BSB & BSB & BSB \\
\hline
\end{tabular}

\section{CONCLUSION}

In this research, IoT is used to build a system that can help stimulate and train child fine motor development in aspects of eye and hand coordination. The functionality and performance of the system work $100 \%$ according to predetermined component functions, as well as in reading accuracy for the scenario of throwing distances of 1 meter and 1.5 meters. In addition, the average delay time for every hole is 0.62 seconds. The delay value can still be tolerated and does not interfere with the game when the child assessment is conducted. The child assessment involved 4 children, the results obtained that 3 children are in the Well Development (BSH) stage and 1 child in Very Well Development (BSB) stage. 


\section{REFERENCES}

[1] J. W. Santrock, Child development, 10th ed. Boston: McGraw-Hill, 2004.

[2] Government of Indonesia, Undang-Undang No. 20 Tahun 2003 Tentang Sistem Pendidikan Nasional. Ministry of Education and Culture, 2003.

[3] H. Gümüşdağ, Effects of Pre-school Play on Motor Development in Children, ujer, vol. 7, no. 2, pp. 580-587, Feb. 2019, doi: 10.13189/ujer.2019.070231.

[4] A. Cronin and M. Mandich, Human development and performance throughout the lifespan. Boston, MA: Cengage Learning, 2016.

[5] L. A. Harris, CliffsAP psychology. Hoboken, NJ: Wiley Pub, 2005.

[6] S. Mugianti, T. Setijaningsih, and K. Fransiska, Motoric Development of 3-5 Years Old Obesity Toddler, JNK JOURNAL, vol. 5, no. 1, pp. 046-052, Apr. 2018, doi: 10.26699/jnk.v5i1.ART.p046-052.

[7] S. B. Flora, Fine motor fun: hundreds of developmentally ageappropriate activities designed to improve fine motor skills. Minneapolis, Minn.: Key Education Publishing Co., 2006.

[8] L. Ph, D. Armitasari, and Y. Susanti, Pengaruh Stimulasi Motorik Halus Terhadap Tahap Perkembangan Psikososial Anak Usia Pra Sekolah, JPKI, vol. 4, no. 1, p. 30, Jun. 2018, doi: 10.17509/jpki.v4i1.12340.

[9] Government of Indonesia, Petunjuk Teknis Penggunaan Buku Kesehatan Ibu dan Anak. Ministry of Health, 2015.

[10] United States Government, Individuals with Disabilities Education Act. U.S. Department of Education, 1990.

[11] W. K. Frankenburg and J. B. Dodds, The Denver Developmental Screening Test, The Journal of Pediatrics, vol. 71, no. 2, pp. 181-191, Aug. 1967, doi: 10.1016/S0022-3476(67)80070-2.

[12] United States Government, CDC's Developmental Milestones. United States Department of Health and Human Services, 2014.

[13] S. M. Grantham-McGregor, S. P. Walker, S. M. Chang, and C. A. Powell, Effects of early childhood supplementation with and without stimulation on later development in stunted Jamaican children, The American Journal of Clinical Nutrition, vol. 66, no. 2, pp. 247-253, Aug. 1997, doi: 10.1093/ajcn/66.2.247.

[14] I. Arta Utomo, M. Ramli, and Furaidah, Penerapan Strategi Bermain melalui Media Busy Book untuk Meningkatkan Fisik Motorik Halus Anak Usia Dini, Jurnal Pendidikan, vol. 3, no. 12, p. 1594-1598, Dec. 2018, doi: 10.17977/jptpp.v3i12.12553.

[15] B. Provost, B. R. Lopez, and S. Heimerl, A Comparison of Motor Delays in Young Children: Autism Spectrum Disorder, Developmental Delay, and Developmental Concerns, J Autism Dev Disord, vol. 37, no. 2, pp. 321-328, Feb. 2007, doi: 10.1007/s10803-006-0170-6. 
[16] Government of Indonesia, Permendikbud Nomor 51 Tahun 2018. Ministry of Education and Culture, 2018.

[17] J. Du and S. Chao, A study of information security for M2M of IOT, in 2010 3rd International Conference on Advanced Computer Theory and Engineering(ICACTE), Chengdu, China, Aug. 2010, pp. V3-576-V3-579, doi: 10.1109/ICACTE.2010.5579563.

[18] P. Pruet, C. S. Ang, D. Farzin, and N. Chaiwut, Exploring the Internet of 'Educational Things' (IoET) in rural underprivileged areas, in 2015 12th International Conference on Electrical Engineering/Electronics, Computer, Telecommunications and Information Technology (ECTICON), Hua Hin, Cha-am, Thailand, Jun. 2015, pp. 1-5, doi: 10.1109/ECTICon.2015.7207125.

[19] A. Setia Ningsih, Identification of Fine Motor Skill in Play Activity, Universitas Negeri Yogyakarta, Yogyakarta, 2015.

[20] L. Maghfuroh and K. Chayaning Putri, The Effect of Finger Painting to the Development of Fine Motor on Preschool Children in Sartika I Sumurgenuk Kindergarten Babat Lamongan, JHS, vol. 10, no. 1, Apr. 2018, doi: 10.33086/jhs.v10i1.144.

[21] E. de la Guia, V. L. Camacho, L. Orozco-Barbosa, V. M. Brea Lujan, V. M. R. Penichet, and M. Lozano Perez, Introducing IoT and Wearable Technologies into Task-Based Language Learning for Young Children, IEEE Trans. Learning Technol., vol. 9, no. 4, pp. 366-378, Oct. 2016, doi: 10.1109/TLT.2016.2557333.

[22] M. Rogers, Cornhole: throwing bags in a hole. Amalgam Studio, 2011.

[23] J. Favorito, Sports publicity: a practical approach, 3rd edition. Abingdon, Oxon ; New York, NY: Routledge, 2020.

[24] M. A. Gutiérrez García, M. L. Martín Ruiz, D. Rivera, L. Vadillo, and M. A. Valero Duboy, A Smart Toy to Enhance the Decision-Making Process at Children's Psychomotor Delay Screenings: A Pilot Study, J Med Internet Res, vol. 19, no. 5, p. e171, May 2017, doi: 10.2196/jmir.7533.

[25] M. Maddeppungeng, Buku Panduan Kuesioner Pra Skrining Perkembangan (KPSP). Fakultas Kedokteran Universitas Hasanuddin, 2018.

[26] H. Wajdi, N. A. Suwastika, and R. Yasirandi, Iot architecture that supports the stimulation of gross motor development in children aged 5-6 years using drop box game, regist. j. ilm. teknol. sist. inf., vol. 6, no. 2, p. 119, Jul. 2020, doi: 10.26594/register.v6i2.1958. 